\title{
Pola Pertumbuhan Ayam Silangan Pelung Sentul Kampung Ras Pedaging (IPB D-1) G4 Umur 1-12 Minggu
}

\author{
Growth performance of G4 Crossing Pelung Sentul Kampung Broiler (IPB D-1) Chickens Age1-12 Weeks
}

\author{
R. Habiburahman ${ }^{1}$, S. Darwati ${ }^{2}$, \& C. Sumantri ${ }^{3}$ \\ ${ }^{1}$ Ilmu Produksi dan Teknologi Peternakan, Fakultas Peternakan, IPB \\ ${ }^{2}$ Departemen Ilmu Produksi dan Teknologi Peternakan, Fakultas Peternakan, IPB \\ Jl. Agatis Kampus IPB Dramaga, Bogor 16680 \\ Email koresponden author: restuhabiburahman@gmail.com
}

\begin{abstract}
Kampung chicken is a local Indonesian chicken that comes from red jungle chicken that has been successfully domesticated but has a low productivity. One of method to increase the productivity can be done by crossing a local chicken with a broiler. This research was conducted to examine the growth performance of crossing result G3 interse (pelung, sentul, kampung, broiler) age 1-12 weeks. IPB D-1 G3 chicken measured in this research were 76 DOC, 18 cocks, and 30 hens. $T$ test was used to knowing the differences of body weight, body weight gain, feed consumption, and feed conversion. Based on the research, body weight, growth, and feed conversion of male IPB D-1 chickens was better than female IPB D-1 chickens when 12 weeks age. Body weight of a cock IPB D-1 G4 in 12 week was $1939.9 \mathrm{~g}$ and for a hen was $994.9 \mathrm{~g}$. Feed consumption of rooster IPB D-1 G4 $3468.97 \mathrm{~g}$ and 3339.80 in females with fluctuating body weight growth. Chicken feed conversion IPB D-1 lowest G4 1.579 and 6.430 with the highest. Coefficient of variation on all variables IPB D-1 G4 was high. Performance growth of IPB D-1 G4 still diverse.
\end{abstract}

Keywords: crossbreed, growth performance, local chicken

\section{PENDAHULUAN}

Ayam kampung merupakan ayam lokal Indonesia yang berasal dari ayam hutan merah yang telah berhasil dijinakkan. Akibat dari proses evolusi dan domestikasi, maka terciptalah ayam kampung yang telah beradaptasi dengan lingkungan sekitarnya, sehingga lebih tahan terhadap penyakit dan cuaca dibandingkan dengan ayam ras. Ayam kampung memiliki keunggulan seperti tekstur dan cita rasa daging yang lebih baik dan khas dibandingkan dengan ayam ras pedaging, namun ayam kampung memiliki produktivitas yang masih rendah, sehingga diperlukan upaya-upaya peningkatan produktivitas seperti pengadaan bibit unggul, persilangan (outcrossing), pakan yang berkualitas, dan manajamen yang baik.

Salah satu ciri ayam kampung adalah genetiknya belum seragam dan laju pertumbuhan masih rendah. Produktivitas ayam lokal dapat ditingkatkan melalui persilangan dengan rumpun ayam lainnya. Salah satu cara meningkatkan laju pertumbuhan dengan melakukan persilangan antara ayam lokal dengan ayam ras pedaging. Persilangan antar rumpun ayam tersebut diharapkan menghasilkan ayam dengan produktivitas yang lebih tinggi karena ada pengaruh heterosis dan keunggulan beberapa ayam.

Hapsari (2015) melaporkan bahwa ayam hasil persilangan ayam lokal dengan ayam ras pedaging meningkatkan produktivitas ayam lokal yaitu bobot badan, ukuran tubuh, dan produksi telur. Bobot badan ayam persilangan yang paling berat untuk jantan adalah ayam silangan kampung $\times$ ras pedaging sedangkan untuk betina adalah silangan ras pedaging $\times$ kampung.

Ayam IPB D-1 merupakan ayam F1 persilangan dari hasil jantan pelung dan Sentul bentina dan betina F1 dari jantan kampung dan betina broiler. Ayam PSKB IPB D-1 telah diteliti selama 3 generasi dan dapat mencapai bobot lebih dari $1 \mathrm{~kg}$ pada umur 12 minggu. Ayam IPB D-1 G1 pada umur 11 minggu mencapai bobot badan 1256 g pada jantan dan 1004 pada betina. Ayam jantan IPB D-1 G3 pada umur 12 minggu mencapai bobot 1186 dan 1048 pada betina. Ayam IPB D-1 G2 pada umur yang sama dengan G3 mencapai bobot badan 1618 g pada jantan dan $1411 \mathrm{~g}$ pada betina lebih berat dengan G3. Tujuan penelitian adalah mengevaluasi pola pertemumbuhan ayam silangan pelung Sentul Kampung Ras Pedaging (IPB D-1) G4 Umur 1-12 Minggu. 


\section{MATERI DAN METODE}

\section{Waktu dan Tempat Penelitian}

Penelitian telah dilaksanakan pada bulan Januari sampai Juli 2017. Lokasi penelitian di Laboratorium Lapang Pemuliaan dan Genetika Ternak, Fakultas Peternakan, Institut Pertanian Bogor.

\section{Alat}

Peralatan yang digunakan pada penelitian ini adalah 3 kandang koloni berukuran $2 \mathrm{~m} \times 1,5 \mathrm{~m}$ dan 5 kandang DOC berukuran $1,5 \mathrm{~m} \times 1,5 \mathrm{~m}$ untuk 5 periode, kandang yang disekat untuk ayam berumur 1-5 minggu sedangkan kandang bambu untuk ayam berumur 6-12 minggu. Alat lain yang digunakan untuk pemeliharaan ayam adalah tempat pakan, tempat minum, ember, gayung, brooder, egg tray, dan mesin tetas. Pengambilan data yang dilakukan dalam penelitian ini menggunakan alat berupa timbangan digital dengan ketelitian $0,5 \mathrm{~g}$. Alat lain yang dibutuhkan yaitu tabulasi data pertambahan bobot badan dan alat tulis.

\section{Bahan}

Bahan yang digunakan pada penelitian ini adalah ayam jantan dan betina hasil persilangan pelung-sentulkampung-ras pedaging generasi ketiga (IPB D-1 G3) dengan sesamanya untuk memperoleh keturunannya yaitu G4. Ayam IPB D-1 G3 sebagai tetua sebanyak 10 ekor terdiri atas 2 ekor jantan dan 8 ekor betina. Jenis ayam yang digunakan dalam penelitian ini disajikan dalam Tabel 1. Performa jenis ayam persilangan yang digunakan dapat dilihat pada Gambar 1, 2, dan 3. Bahan lain yang dibutuhkan adalah pakan komersial untuk ayam pedaging fase starter berbentuk crumble, dedak padi, air, vita chick, sekam, vaksin ND, dan formalin.

Tabel 1. Jenis ayam persilangan yang digunakan dalam penelitian

\begin{tabular}{lcc}
\hline Jenis Ayam & Jenis Kelamin & Jumlah (ekor) \\
\hline IPB D-1 G3 & Jantan & 2 \\
(tetua) & Betina & 8 \\
IPB D-1 G4 & Jantan & 18 \\
(anak) & Betina & 30 \\
\hline
\end{tabular}

Keterangan: P: pelung, S: sentul, K: kampung, B: ras pedaging, G3: generasi ke-tiga G4: generasi ke-empat

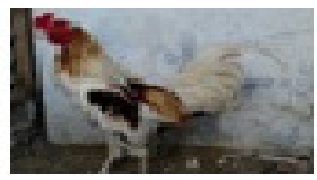

(A)

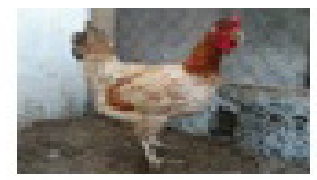

(B)
Gambar 1. Ayam IPB D-1 G3 yang dipakai sebagai tetua: (A) IPB D-1 jantan; (B) IPB D-1 betina

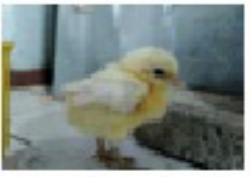

(A)

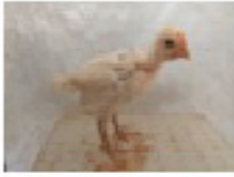

(B)

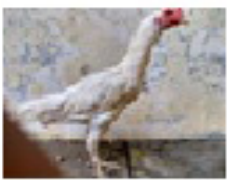

(C)
Gambar 2. Ayam jantan IPB D-1 G4 umur DOC-12 minggu yang dikaji: (A) DOC; (B) 4 minggu; (C) 12 minggu

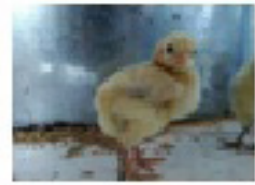

(A)

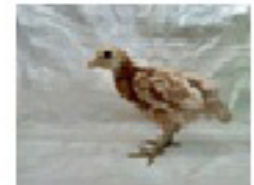

(B)

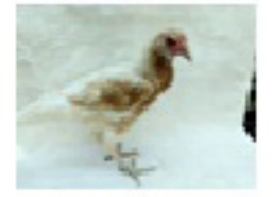

(C)
Gambar 3. Ayam jantan IPB D-1 G4 umur DOC-12 minggu yang dikaji: (A) DOC; (B) 4 minggu; (C) 12 minggu

\section{Prosedur}

\section{Persilangan}

Langkah pertama sebelum penelitian ini adalah melakukan persilangan antara ayam jantan pelung dengan ayam betina sentul yang menghasilkan DOC PS dan persilangan antara ayam jantan kampung dengan ayam betina ras pedaging yang menghasilkan DOC KB, selanjutnya ayam jantan PS disilangkan dengan ayam betina KB yang menghasilkan DOC IPB D-1. Ayam IPB D-1 disilangkan dengan sesama ayam IPB D-1 untuk menghasilkan IPB D-1 keturunan G2. Ayam IPB D-1 G2 disilangkan dengan Ayam IPB D-1 G2 untuk menghasilkan IPB D-1 keturunan G3. Ayam IPB D-1 G3 tersebut dijadikan tetua untuk disilangkan kembali pada penelitian ini sehingga akan diperoleh IPB D-1 keturunan G4. Ilustrasi persilangan ayam yang dikaji dapat dilihat pada Gambar 4.

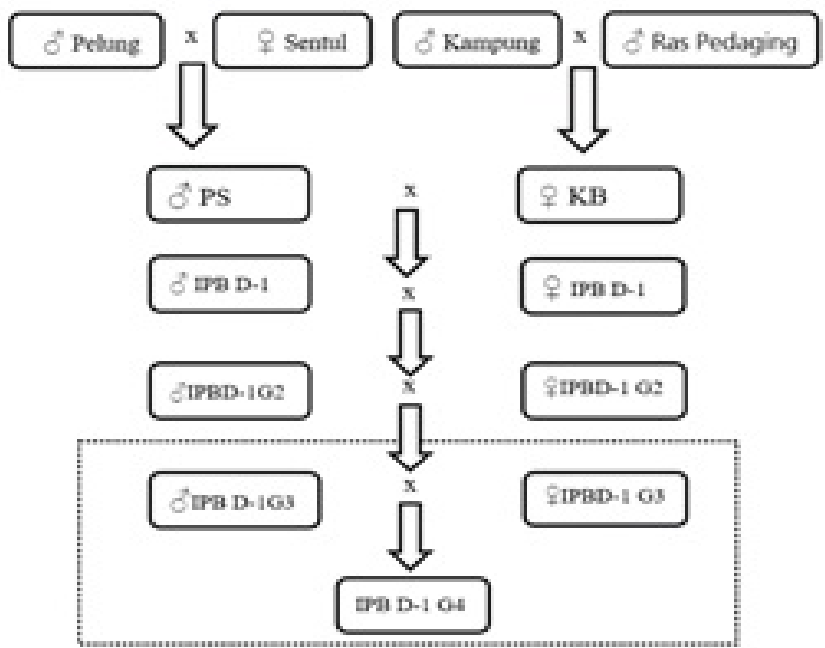

Gambar 4. Ilustrasi persilangan ayam yang dikaji dan bagian (---) diamati pada penelitian ini 


\section{Pengumpulan Telur Tetas dan Penetasan}

Telur tetas hasil perkawinan ayam persilangan dikoleksi pada pagi dan sore hari. Telur dimasukkan ke dalam mesin telur tetas setiap 1 minggu sekali. Mesin tetas difumigasi terlebih dahulu menggunakan $\mathrm{KMnO}_{4}$ formalin $40 \%$ sebelum telur dimasukkan ke dalam mesin tetas. Telur yang dimasukkan harus dibersihkan dahulu menggunakan cairan desinfektan dan diberi keterangan untuk identifikasi. Telur menetas setelah 21 hari pengeraman. DOC yang telah menetas ditimbang menggunakan timbangan digital dan diberi wing band untuk mempermudah identifikasi.

\section{Pemberian Pakan dan Air Minum}

Pakan dan air minum diberikan ad libitum. Pemberian pakan dilakukan sebanyak 2 kali sehari yaitu pagi dan sore hari. Pakan diberikan pada ayam sampai mencapai bobot potong. Pakan komersial untuk ras pedaging fase starter produksi PT Charoen Pokphand Indonesia (511-BRAVO) berbentuk crumble diberikan pada anak ayam berumur sehari (DOC) hingga berumur 3 minggu. Ayam umur 3-4 minggu diberi pakan campuran $80 \%$ pakan komersial dengan 20\% dedak padi. Ayam umur 4-5 minggu diberi pakan campuran $70 \%$ pakan komersial dengan 30\% dedak padi. Ayam umur 5-12 minggu diberi pakan campuran $60 \%$ pakan komersial dengan $40 \%$ dedak padi. Pakan campuran dianalisis proksimat. Kandungan nutrisi pakan yang digunakan dalam penelitian ini dapat dilihat di Tabel 2.

Tabel 2. Kandungan nutrisi pakan

\begin{tabular}{lll}
\hline Nutrisi & Pakan Komersil & $\begin{array}{l}\text { Komersil 60\%: } \\
\text { Dedak 40\%(*) }\end{array}$ \\
\hline BK (\%) & 87 & 87,11 \\
Abu (\%) & 7 & 9,05 \\
PK (\%) & $21-23$ & 13,74 \\
BETN (\%) & $57-59$ & 52,98 \\
SK (\%) & 5 & 7,1 \\
LK (\%) & 5 & 4,24 \\
K (\%) & 0,9 & 3,27 \\
F (\%) & 6 & 0,78 \\
Energi (kkal kg-1) & $2900-3000$ & 3676,00 \\
\hline
\end{tabular}

Keterangan: (*) Analisis pakan dari Laboratorium Ilmu dan Teknologi Pakan, Bagian Teknologi dan Industri Pakan Fapet, IPB (2017)

\section{Pemeliharaan}

DOC hasil persilangan yang telah menetas dipelihara. Kandang terlebih dahulu dibersihkan dan dilakukan pengapuran kemudian diberi alas sekam. Pemeliharaan DOC dilakukan di dalam kandang koloni. Kandang tersebut dilengkapi lampu, tempat pakan, dan tempat air minum. Pemeliharaan dilakukan dari DOC yang telah menetas mulai dari periode pertama penetasan. Setiap kandang diisi dengan ayam sesuai dengan umur, periode, dan jenis kelaminnya. Ayam berumur 1 hari sampai 1 minggu diberi air minum dengan tambahan vita chick dan dilakukan vaksinansi ND ketika ayam berumur 3 hari melalui tetes mata. Ayam yang sudah berumur 5-12 minggu dipisahkan berdasarkan jenis kelamin dan dipindahkan ke kandang yang lebih besar. Pengambilan data konsumsi dilakukan setiap minggu dengan cara menimbang pakan yang diberikan dan sisa pakan. Pertambahan bobot badan ayam diukur setiap 1 minggu sekali dan diamati juga mortalitasnya.

\section{Analisis Data}

Data dianalisis secara deskriptif dengan menyajikan rataan $(\overline{\mathrm{X}})$, simpangan baku $(\mathrm{SD})$, dan koefisien keragaman (KK). Laju pertumbuhan untuk menduga pertumbuhan optimal menurut Broody (1945) sebagai berikut :

$$
\mathrm{Wt}=\mathrm{Wo}_{\mathrm{O}} \times \mathrm{e}^{k t}
$$

\section{Keterangan :}

$\mathrm{Wt}=$ bobot badan umur $\mathrm{t}(\mathrm{g})$

Wo = bobot badan umur 0 (awal) $(\mathrm{g})$

$\mathrm{T}=$ umur (minggu)

$\mathrm{k} \quad=$ koefisien laju pertumbuhan

e $\quad=$ konstanta (bilangan natural $=2,7183$ )

Rumus dari laju pertumbuhan relatif $(\mathrm{k})$ menurut Broody (1945) sebagai berikut :

$$
k=\frac{\ln W t-\ln W o}{\left(t_{2}-t_{1}\right)}
$$

Keterangan :

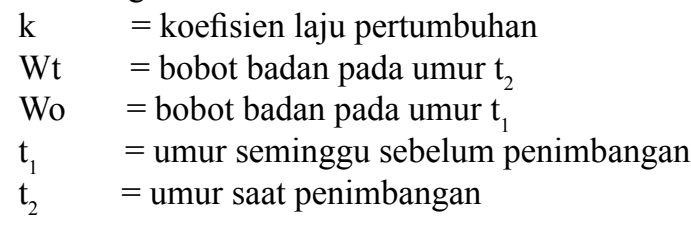

Peubah

Peubah yang diamati adalah konsumsi pakan, konversi pakan, bobot badan, pertambahan bobot badan, dan mortalitas.

1. Konsumsi pakan $\left(\mathrm{g}\right.$ ekor $\left.{ }^{-1} \operatorname{minggu}^{-1}\right)=$ jumlah pakan yang diberikan - sisa pakan:

2. Konversi pakan $=$ membandingkan konsumsi pakan terhadap pertambahan bobot badan:

3. Bobot badan (BB) dalam satuan g per minggu per ekor diperoleh dari hasil penimbangan ayam:

4. Pertambahan bobot badan(PBB) dalam satuan g per minggu per ekor $=$ bobot badan saat penimbanganbobot badan pada minggu sebelumnya:

5. Mortalitas $(\%)=$ membandingkan jumlah ayam mati dengan total ayam yang dipelihara.

\section{HASIL DAN PEMBAHASAN}

\section{Bobot Badan}

Pertumbuhan IPB D-1 saat DOC sampai berumur 4 minggu tidak dibedakan berdasarkan jenis kelamin, karena pada ayam fase starter masih sulit ditentukan jenis kelaminnya. Setelah umur lebih dari 4 minggu baru dilakukan pengelompokan berdasarkan jenis kelamin dengan cara melihat jengger dan bulu pada bagian 
punggung. Setiap minggu bobot badan ayam mengalami perubahan. Rataan bobot badan, koefisien keragaman, dan simpangan baku bobot badan dari ayam IPB D-1 G4 pada umur 1-4 minggu ditampilkan pada Tabel 3, dan umur 5-12 minggu ditampilkan pada Tabel 4.

Tabel 3. Rataan \pm sd (n;KK) bobot badan ayam IPB D-1 G4 umur 1-4 minggu

\begin{tabular}{cc}
\hline Umur (Minggu) & $\begin{array}{c}\text { Bobot Badan } \\
\text { Unsexing }\end{array}$ \\
\hline & ${\text { g } \text { minggu }^{-1} \text { ekor }^{-1}}^{2}$ \\
DOC & $22,87 \pm 2,575(76 ; 11,26)$ \\
1 & $38,28 \pm 8,113(74 ; 21,19)$ \\
2 & $77,68 \pm 16,18(69 ; 20,82)$ \\
3 & $140,90 \pm 30,36(67 ; 21,55)$ \\
4 & $211,03 \pm 45,94(61 ; 21,77)$ \\
\hline
\end{tabular}

Keterangan: P: pelung, S: sentul, K: kampung, B: ras pedaging, sd: standar deviasi, n: jumlah ayam, KK; koefisien keragaman, DOC; Day Old Chick

Bobot ayam IPB D-1 G4 memiliki bobot menetas 22,87 $\mathrm{g}$ lebih rendah jika dibandingkan dengan bobot ayam IPB D-1 sebelumnya, ayam IPB D-1 G1 memiliki bobot badan rata rata 35,36 g, ayam IPB D-1 G2 35,41 g pada jantan dan 33,05 g pada betina, sedangkan pada ayam IPB D-1 G3 26,67 g pada jantan dan 33,05 g pada betina. Bobot tetas ayam IPB D-1 G4 jika dibandingkan dengan ayam lokal lebih kecil. Menurut penelitian Syamsudin (2016) di Warso Unggul Gemilang Farm bobot tetas ayam sentul 32,53 g , pada penelitian Depison (2009) bobot tetas pada ayam pelung $35,12 \mathrm{~g}$. Ayam kampung hasil penelitian Wardono et al. (2014) bahwa ayam kampung memiliki bobot tetas $28,41 \mathrm{~g}$.

Ayam IPB D-1 G4 memiliki daya tetas yang rendah dibandingkan dengan ayam lokal, namu saat bobot akhir ayam IPB D-1 G4 lebih tinggi. Menurut Wardono et al. (2014) berat ayam buras pada umur 10 minggu yaitu 597,71 g sementara pada umur yang sama ayam IPB D-1 G4 pada jantan sudah mencapai bobot 883,6 g dan pada betina 751,8 g. Hal ini dapat dicapai karena pada ayam silangan tersebut terdapat pengaruh individual direct genetic effect, maternal, dan paternal effect serta individual heterosis (Gunawan dan Sartika 2000). Heterosis atau hybrid vigor yaitu jika seekor induk dikawinkan dengan pejantan dari bangsa berbeda maka turunan yang diperoleh akan lebih baik dari tetuanya seperti bobot lahir, laju pertumbuhan (Salamena 2003). Individual direct genetic effect adalah efek genetik langsung yang dikeluarkan oleh individu yang dipengaruhi oleh gen ternak itu sendiri, lingkungan, dan interaksi antara gen dengan lingkungan (Cheverud and Moore 1994; Moore et al. 1997). Chapman (1985) mendefinisikan efek maternal sebagai pengaruh, kontribusi atau dampak pada fenotipe dari sebuah individu yang disebabkan langsung oleh fenotipe induknya.

Bobot badan pada umur 12 minggu ayam IPB D-1 G4 jantan 1 193,90 g lebih besar dibandingkan bobot badan ayam IPB D-1 G4 betina yaitu 994,90 g. Namun jika dibandingkan generasi sebelumnya bobot badan IPB D-1 G4 lebih rendah dari IPB D-1 G1 dan G2. Pada G1 umur 11 minggu sudah dapat mencapai $1256 \mathrm{~g}$ pada jantan dan 1004 g pada betina. Ayam IPB D-1 G2 umur 12 minggu mencapai bobot $1618 \mathrm{~g}$ pada jantan dan $1411 \mathrm{~g}$ pada betina. Ayam IPB D-1 G3 memiliki bobot badan tidak jauh berbeda dengan G4, pada jantan umur 12 minggu mencapai bobot 1 $186 \mathrm{~g}$ dan betina $1048 \mathrm{~g}$. Rata-rata bobot badan ayam IPB D-1 G4 diperoleh dari data rentang 978-1620 g pada jantan dan betina 857-1346 g.

Hasil pengamatan bobot badan ayam IPB D-1 G4 lebih tinggi jika dibandingkan hasil penelitian Suryaman (2001) ayam kampung pada umur 12 minggu memiliki bobot badan untuk jantan bahwa $1067,6 \mathrm{~g}$ dan betina 899,5 g. Kurnia (2011) mengatakan bobot ayam sentul umur 12 minggu yaitu pada jantan 532,1 g dan betina 459,2 g. Gunawan et al. (1998) menyebutkan hasil persilangan ayam kampung dan pelung umur 12 minggu mencapai 1 014,3 g dan 918,57 g pada ayam kampung. Persilangan yang dilakukan memperbaiki pertumbuhan ayam kampung karena bobot yang dihasilkan lebih besar.

Tabel 4. Rataan bobot badan ayam IPB D-1 G4 umur 5-12 minggu

\begin{tabular}{|c|c|c|}
\hline \multirow[t]{2}{*}{ Umur (Minggu) } & \multicolumn{2}{|c|}{ Bobot Badan } \\
\hline & Jantan & Betina \\
\hline & \multicolumn{2}{|c|}{ g minggu $^{-1}$ ekor $^{-1}$} \\
\hline 5 & $297,5 \pm 60,80(22 ; 20,44)$ & $273,18 \pm 54,17(34 ; 19,83)$ \\
\hline 6 & $406,6 \pm 65,70(21 ; 16,16)$ & $362,9 \pm 74,40(34 ; 20,50)$ \\
\hline 7 & $514,9 \pm 61,80(21 ; 12,01)$ & $451,0 \pm 89,40(34 ; 19,82)$ \\
\hline 8 & $636,4 \pm 87,30(20 ; 13,72)$ & $542,4 \pm 102,50(33 ; 18,89)$ \\
\hline 9 & $756,6 \pm 89,00(18 ; 11,77)$ & $644,2 \pm 127,40(32 ; 19,77)$ \\
\hline 10 & $883,6 \pm 107,50(18 ; 12,17)$ & $751,8 \pm 128,40(32 ; 17,08)$ \\
\hline 11 & $1014,3 \pm 124,40(18 ; 12,27)$ & $868,3 \pm 142,10(30 ; 16,37)$ \\
\hline 12 & $1193,9 \pm 142,80(18 ; 11,96)$ & $994,9 \pm 153,30(30 ; 15,41)$ \\
\hline
\end{tabular}

Keterangan: P: pelung, S: sentul, K: kampung, B: ras pedaging, sd: standar deviasi, n: jumlah ayam, KK; koefisien keragaman, DOC; Day Old Chick. 
Hanafiah (1991) mengatakan koefisien keragaman termasuk besar pada kondisi homogen jika lebih dari 10\%. Koefisien keragaman pada ayam IPB D-1 G4 memiliki nilai terendah $11,96 \%$ pada jantan umur 12 minggu dan tertinggi 20,82 pada umur 2 minggu. Ayam IPB D-1 G3 memiliki koefisien keragaman terendah $9,78 \%$ pada betina umur 12 minggu dan tertinggi $24,75 \%$ pada betina umur 2 minggu. Koefisien keragaman ayam IPB D-1 G4 tidak berbeda dengan ayam IPB D-1 G3 namun termasuk besar menurut literatur.

Tabel 5. Rataan pertumbahan bobot badan ayam IPB D-1 G4 umur 1-4 minggu

\begin{tabular}{cc}
\hline Minggu Ke- & $\begin{array}{c}\text { Laju Pertumbuhan } \\
\text { Unsexing }\end{array}$ \\
\hline & g minggu $^{-1}$ ekor $^{-1}$ \\
2 & $15,47 \pm 7,21(46,60)$ \\
3 & $37,11 \pm 15,97(43,03)$ \\
4 & $62,85 \pm 18,37(29,23)$ \\
\hline
\end{tabular}

Keterangan: P: pelung, S: sentul, K: kampung, B: ras pedaging, sd: standar deviasi, KK: koefisien keragaman

\section{Pertambahan Bobot Badan}

Pertambahan bobot badan merupakan salah satu faktor penting yang dipertimbangkan dalam mengamati performa. Adapun simpangan baku dan koefisien keragaman pertambahan bobot badan umur 1-4 minggu disajikan pada Tabel 5 dan pertambahan bobot badan umur 5-12 minggu disajikan pada Tabel 6. Tabel 5 menunjukan pertumbuhan bobot badan ayam IPB D-1 G4 mengalami kenaikan pada umur 1-4 minggu, sementara hasil pengamatan pada Tabel 6 terdapat penurunan pertumbuhan bobot badan pada ayam IPB D-1 G4 jantan pada umur 7 dan 9 minggu dan pada betina umur 5, 7, dan 9 minggu. Penurunan pertumbuhan bobot badan pada umur 7 dan 9 minggu diduga karena perubahan cuaca yang tidak menentu sehingga mempengaruhi suhu dan kelembaban yang menyebabkan ternak menurunkan konsumsi pakan dan mengkoversi pakan untuk menyesuaikan tubuh dengan kondisi lingkungan.
Laju pertumbuhan ayam IPB D-1 G4 jantan pada minggu ke-5 sampai 12 memiliki tingkat pertumbuhan yang lebih baik jika dibandingkan dengan ayam IPB D-1 G4 betina. Laju pertumbuhan pada ayam IPB D-1 G1 1054 g pada jantan dan $838 \mathrm{~g}$ pada betina. Ayam IPB D-1 G2 1 593,54 g pada jantan dan $1454,54 \mathrm{~g}$ pada betina, sedangkan pada ayam jantan IPB D-1 G3 1 160,32 g dan pada betina 1 022,88 g. Pertumbuhan ayam IPB D-1 G4 sesuai Rose (1997) bahwa pertambahan bobot badan ayam berlangsung sesuai dengan kondisi fisiologis ayam, yaitu bobot badan ayam akan berubah ke arah bobot badan dewasa. Perubahan bobot badan membentuk kurva sigmoid yaitu meningkat perlahan-lahan kemudian cepat dan perlahan lagi atau berhenti.

Hasil pengamatan Tabel 5 dan 6 dapat dilihat pertambahan bobot hidup ayam kampung dari umur 0-12 minggu berjalan lebih cepat pada minggu ke-4. Hal ini sesuai dengan yang dikemukakan oleh Cresswell dan Gunawan (1982), bahwa ayam kampung pertumbuhannya sangat cepat pada umur 4-12 minggu. Hal ini menunjukkan bahwa secara fisiologis anak ayam telah mampu untuk mengkonsumsi pakan secara optimal, kemudian kondisi tulang-tulang yang mendukung kerangka tubuh yang masih tulang rawan memungkinkan untuk cepat tumbuh, sehingga dengan konsumsi pakan yang banyak serta seimbang unsur imbangan proteinnya maka unsur pakan dimetabolisir untuk kegunaan hidup pokok dan pertumbuhan. Pertambahan bobot hidup ayam kampung sesuai dengan pola pertumbuhan yang normal, yaitu dimulai secara lambat kemudian cepat dan akhirnya lambat kembali (Anggorodi 1984).

\section{Laju Pertumbuhan}

Kurva laju pertumbuhan ayam IPB D-1 G4 dibandingkan dengan pendugaan pertumbuhan optimal ditampilkan pada Gambar 5. Laju pertumbuhan ayam IPB D-1 G4 dapat dilihat pada Gambar 5. Perfoma pertumbuhan ayam IPB D-1 G4 jantan dan betina lebih baik jika dibandingkan pedugaan pertumbuhan optimal jantan $\left(\mathrm{W}_{\mathrm{t}}=\right.$ $\left.\mathrm{W}_{\mathrm{o}} \times \mathrm{e}^{0,330 \mathrm{t}}\right)$ dan betina $\left(\mathrm{W}_{\mathrm{t}}=\mathrm{W}_{\mathrm{o}} \times \mathrm{e}^{0,314 t}\right)$. Laju pertumbuhan yang lebih tinggi dengan pendugaan pertumbuhan optimal dapat diartikan ayam belum mencapai titik infleksi yaitu belum terjadi perlambatan pertumbuhan.

Tabel 6. Rataan pertumbahan bobot badan ayam IPB D-1 G4 umur 5-12 minggu

\begin{tabular}{ccc}
\hline Minggu Ke- & \multicolumn{2}{c}{ Laju Pertumbuhan } \\
\cline { 2 - 3 } & Jantan & Betina \\
\hline & & g minggu $^{-1}$ ekor $^{-1}$ \\
6 & $69,83 \pm 44,13(63,20)$ & $59,08 \pm 36,10(61,10)$ \\
7 & $97,17 \pm 45,55(46,88)$ & $78,52 \pm 47,32(60,26)$ \\
8 & $98,87 \pm 43,96(44,47)$ & $73,62 \pm 46,04(62,54)$ \\
9 & $103,00 \pm 59,50(57,78)$ & $64,67 \pm 44,75(69,19)$ \\
10 & $85,00 \pm 55,80(65,63)$ & $75,74 \pm 60,03(79,25)$ \\
11 & $99,30 \pm 69,20(69,67)$ & $82,74 \pm 55,34(66,88)$ \\
12 & $102,30 \pm 71,20(69,56)$ & $89,59 \pm 60,80(67,86)$ \\
LDOC-12 & $140,60 \pm 94,00(66,87)$ & $97,40 \pm 68,60(70,42)$ \\
\hline
\end{tabular}

Keterangan: P: pelung, S: sentul, K: kampung, B: ras pedaging, sd: standar deviasi, KK; koefisien keragaman 


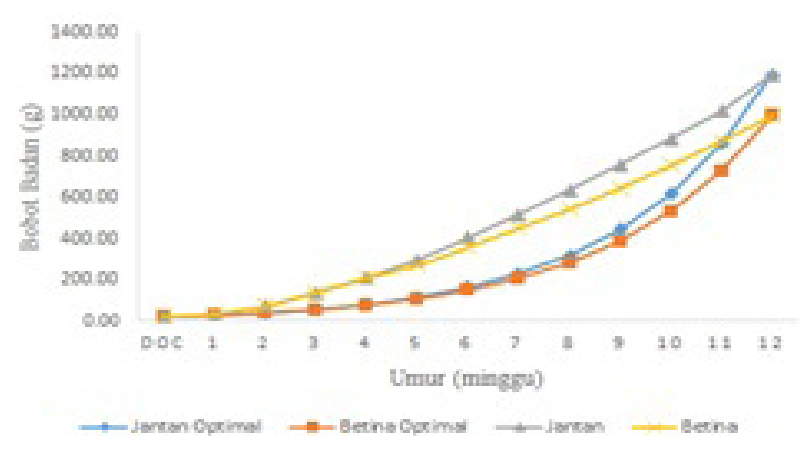

Gambar 5. Kurva laju pertumbuhan pada ayam IPB D-1 G4

\section{Konsumsi Pakan}

Ayam persilangan IPB D-1 dengan sesamanya pada umur 0-4 minggu belum dilakukan pemisahan berdasarkan jenis kelamin sehingga masih disatukan dalam 1 kandang. Rataan, simpangan baku dan koefisien keragaman konsumsi pakan umur 1-4 minggu disajikan pada Tabel 7. Konsumsi pakan ayam IPB D-1 G4 umur 0-4 minggu 361,07 g. Konsumsi ayam IPB D-1 G4 lebih rendah jika dibandingkan dengan penelitian Hasyim (2015) bahwa konsumsi pakan ayam IPB D-1 G1 umur 0-4 minggu 518 g. Penelitian Said (2016) konsumsi pakan ayam IPB D-1 G2 umur 0-4 minggu 440,89 g sementara hasil penelitian Nurhuda (2017) ayam IPB D-1 G3 memiliki konsumsi pakan 469,65.

Hasil pengamatan konsumsi pakan pada ayam jantan IPB D-1 G4 jantan lebih tinggi yaitu 3 468,97 g dibandingkan dengan ayam betina yaitu 3339,80 g sesuai dengan Hasnelly dan Kuntoro (2006) bahwa ayam jantan mengonsumsi pakan yang lebih banyak dibandingkan ayam betina. Konsumsi pakan pada Tabel 7 dan 8 dapat dilihat setiap minggunya ada peningkatan jumlah pakan yang dikonsumsi oleh ayam IPB D-1 G4. Hal ini sesuai dengan Ensminger (1992) bahwa konsumsi pakan meningkat seiring dengan meningkatnya bobot badan. Selain bobot badan, konsumsi ransum dipengaruhi oleh jenis kelamin ayam, dan keaktifannya (Rumiyani et al. 2011).

Konsumsi pakan ayam IPB D-1 G4 lebih tinggi dibandingkan dengan G2 dan G3. Ayam jantan IPB D-1
G2 mengkonsumsi pakan 3 468,04 g dan betina 3 296,01 g (Said 2016), sedangkan ayam jantan IPB D-1 G3 mengkonsumsi pakan 2652,82 g dan betina $2576,47 \mathrm{~g}$ (Nurhuda 2017). Konsumsi pakan ayam IPB D-1 G1 lebih tinggi dibandingkan G4 pada jantan ayam IPB D-1 G1 jantan mengkonsumsi $4565 \mathrm{~g}$ dan betina $4414 \mathrm{~g}$ (Hasyim 2015).

Tingginya konsumsi pakan ayam IPB D-1 G4 dikarenakan ayam ditempatkan di kandang umbaran. Menurut Parakkasi (1999), tingkat konsumsi ransum dipengaruhi oleh hewannya sendiri, makanan yang diberikan dan lingkungan tempat hewan tersebut dipelihara.

Tabel 7. Rataan konsumsi pakan ayam IPB D-1 G4 umur 1-4 minggu

\begin{tabular}{cc}
\hline Umur (Minggu) & $\begin{array}{c}\text { Konsumsi Pakan } \\
\text { Unsexing }\end{array}$ \\
& g minggu $^{-1}$ ekor $^{-1}$ \\
1 & $27,26 \pm 3,26(11,97)$ \\
2 & $60,62 \pm 12,41(20,47)$ \\
3 & $114,94 \pm 19,81(17,23)$ \\
4 & $158,25 \pm 20,23(12,78)$ \\
\hline EDOC-4 & 361,07 \\
\hline
\end{tabular}

Keterangan: P: pelung, S: sentul, K: kampung, B: ras pedaging, sd: standar deviasi, KK: koefisien keragaman

Perhitungan jumlah pakan dihitung dengan cara pakan yang diberikan selama penelitian dikurangi sisa pakan yang tidak termakan dibagi jumlah ayam. Ayam IPB D-1 G4 memiliki komposisi $75 \%$ gen ayam lokal sehingga masih muncul sifat ayam lokal seperti mengais sekam sehingga pakan tercampur dengan sekam sehingga pakan tidak layak dimakan ayam.

\section{Konversi Pakan}

Rataan, simpangan baku, dan koefisien keragaman konversi pakan umur 1-4 minggu disajikan pada Tabel 9 dan umur 5-6 minggu pada Tabel 10. Konversi pakan merupakan perbandingan antara jumlah ransum yang dikonsumsi dengan pertumbuhan berat badan. Angka konversi ransum

Tabel 8. Rataan konsumsi pakan ayam IPB D-1 G4 umur 5-12 minggu

\begin{tabular}{|c|c|c|}
\hline \multirow[t]{2}{*}{ No } & \multicolumn{2}{|c|}{ Konsumsi Pakan } \\
\hline & Jantan & Betina \\
\hline & \multicolumn{2}{|c|}{$\mathrm{g} \mathrm{minggu}^{-1}$ ekor $^{-1}$} \\
\hline 5 & $214,19 \pm 22,63(10,57)$ & $219,16 \pm 24,48(11,17)$ \\
\hline 6 & $255,54 \pm 19,03(7,45)$ & $252,91 \pm 29,26(11,57)$ \\
\hline 7 & $323,99 \pm 39,16(12,09)$ & $301,40 \pm 47,49(15,76)$ \\
\hline 8 & $350,45 \pm 30,63(8,74)$ & $343,82 \pm 49,54(14,41)$ \\
\hline 9 & $416,61 \pm 37,67(9,04)$ & $395,10 \pm 55,70(14,10)$ \\
\hline 10 & $464,61 \pm 37,79(8,13)$ & $442,00 \pm 60,20(13,62)$ \\
\hline 11 & $512,86 \pm 37,09(7,23)$ & $486,24 \pm 53,34(10,97)$ \\
\hline 12 & $568,72 \pm 39,69(6,98)$ & $538,10 \pm 59,10(10,98)$ \\
\hline$\Sigma 5-12$ & 3106,97 & 2978,73 \\
\hline
\end{tabular}

Keterangan: P: pelung, S: sentul, K: kampung, B: ras pedaging, sd: standar deviasi, KK: koefisien keragaman 
yang kecil berarti jumlah ransum yang digunakan untuk menghasilkan $1 \mathrm{~kg}$ daging semakin sedikit (Edjeng dan Kartasudjana 2006). Konversi pakan ayam IPB D-1 G4 umur 0-4 minggu fluktuatif dengan konversi pakan terendah pada umur 2 minggu yaitu 1,579 dan tertinggi pada umur 4 minggu 5,670.

Tabel 9. Rataan konversi pakan ayam IPB D-1 G4 umur 1-4 minggu

\begin{tabular}{cc}
\hline Umur (Minggu) & $\begin{array}{c}\text { Konversi Pakan } \\
\text { Unsexing }\end{array}$ \\
\hline 1 & $2,030 \pm 1,142(56,25)$ \\
2 & $1,579 \pm 0,709(44,89)$ \\
3 & $2,046 \pm 0,813(39,72)$ \\
4 & $5,670 \pm 23,020(406,24)$ \\
\hline Rataan 1-4 & 2,831 \\
\hline
\end{tabular}

Keterangan: P: pelung, S: sentul, K: kampung, B: ras pedaging, sd: standar deviasi, KK: koefisien keragaman.

Lacy dan Vest (2000) mengatakan beberapa faktor utama yang mempengaruhi konversi ransum adalah genetik, kualitas ransum, penyakit, temperatur, sanitasi kandang, ventilasi, pengobatan, dan manajemen kandang. Tingginya konversi pakan pada umur 4 minggu diduga faktor lingkungan yang tidak mendukung. Cuaca yang tidak menentu membuat ayam mudah stress sehingga nafsu ayam akan menurun sesuai dengan literatur, ayam kampung pada suhu lingkungan yang tinggi $\left(25-31^{\circ} \mathrm{C}\right)$ menunjukkan penurunan produktivitas, serta pertumbuhan yang lambat (Gunawan dan Sihombing 2004) dan diperkuat oleh Farrel (1979) bahwa ayam kurang toleran terhadap perubahan suhu lingkungan, sehingga lebih sulit melakukan adaptasi terhadap perubahan suhu lingkungan, terutama setelah ayam tersebut berumur lebih dari 3 minggu.

Hasil pengamatan pada Tabel 10 terlihat ayam IPB D-1 G4 jantan memiliki konversi pakan yang lebih rendah dibandingkan betina dari umur 5 minggu hingga umur 12 minggu. Ayam IPB D-1 jantan memiliki nilai konversi pakan 3,881 sedangkan pada betina 4,836. Ayam IPB D-1 G4 jantan memiliki konversi pakan terendah pada umur 6 minggu yaitu 2,808 dan tertinggi pada umur 11 minggu
5,251 sementara pada betina konversi pakan terendah pada umur 6 minggu yaitu 3,266 dan tertinggi pada umur 12 minggu yaitu 6,430. Tingginya konversi pakan ayam IPB D-1 G4 dipengaruhi oleh tingginya konsumsi pakan yang tidak diikuti oleh tingginya pertambahan bobot badan sehingga diperoleh hasil perhitungan konversi pakan yang tinggi.

Salah satu penyebab tingginya konversi pakan adalah kandungan pakan yang kurang baik. Menurut Fitasari et al. (2016) ayam kampung dengan pemberian pakan kandungan protein $19 \%$ memberikan hasil terbaik pada konsumsi pakan, pertambahan bobot badan, FCR, dan kecernaan protein. Pada penelitian IPB D-1 G4 pemberian pakan yang dicampurkan dengan dedak menghasilkan protein kasar pakan sebesar 13,74\%. Hal ini lebih rendah dari literatur dan diduga salah satu penyebab pertumbuhan ayam IPB D-1 G4 tidak optimal.

Ayam IPB D-1 G4 lebih rendah jika dibandingkan dengan ayam IPB D-1 G1, ayam IPB D-1 G1 memiliki konversi pakan pada jantan 3,78 dan betina 5,07. akan tetapi konversi pakan pada ayam IPB D-1 G4 lebih tinggi jika dibandingkan dengan ayam IPB D-1 G2 dan G3. Ayam IPB D-1 G2 memiliki konversi pakan 3,12 pada jantan dan 3,03 pada betina sedangkan ayam IPB D-1 G3 memiliki konversi pakan 2,71 pada jantan dan 2,96 pada betina.

\section{Mortalitas}

Angka mortalitas ayam IPB D-1 G4 yang dipelihara selama penelitian dapat disajikan pada Tabel 11. Penyakit yang menyerang ayam pada minggu ke-5 dan 6 diduga adalah penyakit Chronic Respiratory Disease (CRD). Perubahan cuaca yang terjadi selama penelitian sangat mempengaruhi kondisi tubuh ayam. Cuaca yang tidak menentu menyebabkan kondisi tubuh ayam menurun sehingga lebih mudah terinfeksi bibit penyakit. Amer et al. (2009) menyatakan bahwa pemeliharaan ayam dalam kandang dengan kepadatan yang tinggi dan sirkulasi udara yang kurang baik dapat menyebabkan ternak ayam terinfeksi bakteri Mycoplasma gallisepticum.

Mycoplasma gallisepticum menyerang saluran pernafasan di bagian kantong udara. Kantong udara menjadi dipenuhi mukus. Tahap infeksi yang lebih akut

Tabel 10. Rataan konversi pakan ayam IPB D-1 G4 umur 5-12 minggu

\begin{tabular}{ccc}
\hline Minggu Ke- & \multicolumn{2}{c}{ Konversi Pakan } \\
\cline { 2 - 3 } & Jantan & Betina \\
\hline 5 & $3,365 \pm 3,640(108,17)$ & $4,559 \pm 4,075(89,39)$ \\
6 & $2,808 \pm 1,363(48,54)$ & $3,266 \pm 1,732(53,04)$ \\
7 & $3,672 \pm 3,022(82,32)$ & $3,778 \pm 1,872(49,56)$ \\
8 & $3,487 \pm 1,658(47,55)$ & $5,278 \pm 3,028(57,37)$ \\
9 & $4,626 \pm 2,854(61,70)$ & $6,040 \pm 5,340(88,47)$ \\
10 & $4,216 \pm 1,706(40,47)$ & $4,438 \pm 1,430(32,23)$ \\
11 & $5,251 \pm 4,157(79,18)$ & $4,901 \pm 2,261(46,13)$ \\
12 & $3,613 \pm 1,523(42,16)$ & $6,430 \pm 8,71(135,62)$ \\
\hline Rataan 5-12 & 3,881 & 4,836 \\
\hline
\end{tabular}

Keterangan: P: pelung, S: sentul, K: kampung, B: ras pedaging, sd: standar deviasi, KK: koefisien keragaman. 
Tabel 11. Persentase mortalitas ayam IPB D-1 G4

\begin{tabular}{ccc}
\hline Umur & Jenis Kelamin & $\begin{array}{c}\text { Mortalitas } \\
(\mathrm{n} \text { populasi) }\end{array}$ \\
\hline Minggu & Unsexed & $18,42(76)$ \\
DOC-4 & Jantan & $21,74(23)$ \\
& Betina & $23,08(39)$ \\
\hline
\end{tabular}

Keterangan: P: pelung, S: sentul, K: kampung, B: ras pedaging, DOC: Day Old Chick

menyebabkan mukus berwarna kuning dan kental (Bell dan Weaver 2002). Gejala yang terlihat pada ayam muda adalah adanya indikasi kesulitan bernafas seperti bersin dan nafas yang bersuara (ngorok). Menurut Bell dan Weaver (2002) gejala CRD pada ayam dewasa adalah ayam terlihat depresi dan tidak aktif, konsumsi ransum menurun namun mortalitasnya rendah. Ayam IPB D-1 G4 pada saat kondisi unsexed memiliki tingkat mortalitas 18,42\% dan pada kondisi setelah adanya pemisahan berdasarkan jenis kelamin. Pada jantan tingkat mortalitas $21,74 \%$ dan pada betina $23,08 \%$.

\section{KESIMPULAN}

Ayam IPB D-1 G4 jantan mencapai bobot 1 199,9 g dan 994,9 g pada betina. Konsumsi pakan ayam jantan IPB D-1 G4 3468,97 g dan 3339,80 pada betina dengan pertumbuhan bobot badan yang fluktuatif. Konversi pakan ayam IPB D-1 G4 terendah 1,579 pada minggu ke 2 dan tertinggi 6,430 pada betina umur 12 minggu. Koefisien keragaman bobot badan, konsumsi, konversi ayam IPB D-1 G4 di atas $10 \%$ tergolong tinggi. Performa pertumbuhan IPB D-1 G4 masih beragam.

\section{DAFTAR PUSTAKA}

Amer, M. M., K. M. El-Bayomi, M. S. G. Zenab, \& A. E. A. Hanafei. 2009. Field study on control of chronic respiratory disease in vertically infected broiler chicks. J. BS Vet Med.19 (1): 27-33.

Anggorodi, R. 1984. Ilmu Makanan Ternak Umum. Gramedia Pustaka Utama, Jakarta.

Cresswell, D. C., B. Gunawan. 1982. Pertumbuhan badan dan produksi telur dari 5 strain ayam sayur pada sistem peternakan intensif. Pros. Seminar Penelitian Peternakan. Bogor (ID). hlm 236-240.

Bell, D. D., W. D. Weaver. 2002. Comercial Chicken Meat and Egg Production. Ed ke-5. Springer Sciencer and Business Media, Inc., New York.

Brody, S. 1945. Bioenergetics and Growth. Reinhold Publishing Corp, New York.

Chapman, A. B. 1985. General and Quantitative Genetics. Elsevier Science $\mathrm{Pb}$, Amsterdam.

Cheverud, J. M., A. J. Moore. 1994. Quantitative genetics and the role of the environment provided by relatives in behavioral evolution. Pp. 67-100 in C. R. B. Boake, ed. Quantitative genetic studies of behavioral evolution. Univ. of Chicago Pr, Chicago.
Depison. 2009. Karakteristik kuantitatif dan kualitatif hasil persilangan beberapa ayam lokal. J. Ilmu dan Peternakan. 12(1):7-13.

Edjeng, S., R. Kartasudjana. 2006. Manajemen Ternak Unggas. Penebar Swadaya, Jakarta.

Ensminger, M. A. 1992. Poultry Science (Animal Agriculture Series). Ed ke-3. Illionis Interstate Publisher Inc, Danville Virginia.

Farell, D. J. 1979. Pengaruh dari suhu terhadap kemampuan biologis dari unggas. Laporan Seminar Ilmu dan Industri Perunggasan 11. Bogor (ID): Pusat Penelitian dan Pengembangan Peternakan.

Fitasari, E., K. Reo, \& N. Niswi. 2016. Penggunaan kadar protein berbeda pada ayam kampung terhadap penampilan produksi dan kecernaan protein. J. IlmuIlmu Peternakan. 26(2): 73-83.

Gunawan, D. T. H. Sihombing. 2004. Pengaruh suhu lingkungan tinggi terhadap kondisi fisiologis dan produktivitas ayam Buras. Wartozoa. 14(1): 31-38.

Gunawan, B., Z. Desmanti, T. Sartika, A. Gozali, K. Dwiyanto, Abubakar, Broto, Wibowo, Juarini E. 1998. Crossbreeding ayam pelung jantan dengan ayam buras betina untuk meningkatkan ayam buras pedaging. Prosiding Seminar Nasional Peternakan dan Veteriner. Bogor (ID): Balai Penelitian Ternak

Gunawan, B., T. Sartika. 2000. Persilangan ayam pelung jantan $\mathrm{x}$ kampung betina hasil seleksi generasi kedua (G2). J. Ilmu Ternak dan Veteriner. 6(1): 21-27.

Hanafiah, H. A. 1991. Rancangan Percobaan : Teori dan Aplikasi. Cetakan kelima. Raja Grafindo Persada, Jakarta.

Hapsari, I. P. 2015. Ukuran tubuh dan produksi telur ayam hasil persilangan ayam lokal dengan ayam ras pedaging. Skripsi. Bogor (ID): Institut Pertanian Bogor.

Hasnelly, Z., A. N. Kuntoro. 2006. Pengaruh perbaikan kualitas dan waktu pemberian pakan terhadap pertumbuhan ayam merawang. Prosiding Seminar Nasional Teknologi Peternakan dan Veteriner. Bangka Belitung (ID): Balai Pengkajian Teknologi Pertanian.

Hasyim, A. R. 2015. Performa hasil persilangan ayam kampung ras pedaging dengan pelung sentul pada umur 0-11 minggu. Skripsi. Bogor (ID): Institut Pertanian Bogor.

Kurnia, Y. 2011. Morfometrik ayam sentul, kampung, dan kedu pada fase pertumbuhan dari umur 1-12 minggu. Skripsi. Bogor (ID): Institut Pertanian Bogor.

Lacy, M., L. R. Vest. 2000. Improving Feed Convertion in Broiler: A Guide for Growers. Springer Science and Business Media Inc, New York.

Moore, A. J., E. D. Brodie, \& J. B. Wolf. 1997. Interacting phenotypes and the evolutionary process.I. Direct and indirect genetic effects of social interactions. Evolution. 51:1352-1362

Nurhuda, S. A. 2017. Pertumbuhan G3 persilangan ayam lokal dengan ayam pedaging umur 1 sampai 12 minggu. Skripsi. Bogor (ID): Institut Pertanian Bogor.

Parakkasi, A. 1999. Ilmu Nutrisi dan Makanan Ternak Ruminan. Universitas Indonesia, Depok.

Rose, S. P. 1997. Principle of Poulty Science. CAB. 
International, New York.

Rumiyani, T., Wihandoyo, \& H. P. Jafendi. 2011. Pengaruh pemberian pakan pengisi pada ayam broiler umur 2228 hari terhadap pertumbuhan, dan kandungan lemak karkas dan daging. Buletin Peternakan. 35(1): 38-49.

Said, Z. 2016. Performa pertumbuhan hasil persilangan ayam lokal dengan ayam ras pedaging (G2) umur 0 sampai 12 minggu. Skripsi. Bogor (ID): Institut Pertanian Bogor.

Salamena, J. F. 2003. Strategi pemuliaan ternak domba pedaging di Indonesia. Makalah Pengantar Falsafah Sains. Disertasi. Bogor (ID), Institut Pertanian Bogor.

Suryaman, A. 2001. Perbandingan morfologi ayam kampung, ayam pelung dan ayam keturunan pertama (F1) persilangan pelung kampung jantan dan betina. pada umur 12 minggu. Skripsi. Bogor (ID): Institut Pertanian Bogor.
Syamsudin, G. H. 2016. Fertilitas, daya tetas, dan bobot tetas ayam sentul warso unggul gemilang farm Bogor. Skripsi. Sumedang (ID): Universitas Padjajaran.

Wardono, H. P., C. Sugihono, H. Kusnadi, \& Suprijono. 2014. Korelasi antara beberapa kriteria peubah produksi. Prosiding Seminar Nasional Inovasi Teknologi Pertanian Spesifik Lokasi. Banjarbaru (ID): Balai Pengkajian Teknologi Pertanian (BPTP) Kalimantan Selatan. 